\title{
AZ EURÓPAI INTEGRÁCIÓ ÉS A TERÜLETI EGYÜTTMÜKÖDÉSEK HATÁSA A PIACGAZDASÁGOK REGIONÁLIS POLITIKÁJÁRA
}

\section{(The influence of European integration and regional cooperation on the regional policy of market economies)}

\section{HORVÁTH GYULA}

\author{
Bevezetés
}

A 70-es évtizedben a fejlett ipari államokban a tömegtermelésen nyugvó monopolista felhalmozás növekedési szakaszát a differenciált piac erổteljes szerepére építố decentralizált gazdasági fejlổdés szakasza váltotta fel. A fejlődés korábbi húzóerejének, a nyersanyagigényes iparnak csökkent a szerepe, a térben sokkal mozgékonyabb és az újfajta telepítési kívánalmakat támasztó szolgáltatásokban dolgozók száma meghaladja azokét, akiket a hagyományos termelôfolyamatokban alkalmaznak.

A fordista nagyüzem helyett a kis-és középüzemekre építő új gazdasági paradigma érezhetổ hatást gyakorolt a regionális politika fejlỏdésére is. A kialakult konszenzusok felbomlottak. A központi kormányok gazdaságpolitikájának homlokterébe a gazdasági szerkezetváltozás került. A központi költségvetés szúkítése, a favorizált új gazdasági ágazatok (a tercier és a kvaterner szektor) átértékelésre kényszerítették a tradicionális regionális politikát. A hagyományos megoldások (magasfokú állami szerepvállalás, centralizált regionális politika, felülrôl-lefelé irányuló ösztönzési rendszer, tốkeberuházások stb.) elveszitették korábbi gazdasági és politikai motívumaikat, új regionális stratégiák körvonalai bontakoztak ki. Nem véletlen, hogy a 70-80-as évtized fordulóján szinte valamennyi nyugat-európai ország új területfejlesztési jogszabályt alkotott, vagy jelentốsen módosította korábbi törvényeit.

A gazdasági korszakváltáshoz igazodó nemzeti regionális politikai változásokkal párhuzamosan zajlott az Európai Közösség regionális politikájának megújítása. Az új stratégia kialakítása részben a tagállamok koncepciói összehangolásának az igényébôl fakadt, részben pedig a Közösség bôvülésével kiélezổdött regionális differenciák mérsékléséhez nyújtott programot és eszközöket.

Ezen közben változott a nyugat-európai országok területi-hatalmi struktúrája is. A gazdasági decentralizáció politikai megnyilvánulása a központi államhatalom és a regionális-helyi kormányzatok közötti új munkamegosztás kialakulása volt. A jogosítványaikban megerốsödött regionális kormányzatok részben arra váltak alkalmassá, hogy az új nemzeti regionális politikában aktív kezdeményezóként léphessenek fel, részben pedig az Európai Közösség reformtörekvéseinek térbeli bázisaivá vâlhassanak 1992 után.

Véleményem szerint a következõ évtizedben a fejlett európai társadalmak regionális politikája a , ,rugalmas" felhalmozás post-fordista gazdaságpolitikájának, a Közös Piac regionális stra- 
tégiájának és a decentralizált hatalomgyakorlásnak, a regionalizmusnak a metszéspontjában fejlôdik majd.

Tanulmảnyomban e két utóbbi komponens elemzésével foglalkozom.

\section{Regionális különbségek a Közösségben}

A Nyugat-Európa legfejlettebb államaiból alakult Európai Közösségben — a határok bốvülésével, a tagországok számának gyarapodásával — a regionális különbségek integrációt befolyásoló szerepe fokozatosan erôsödött. Míg korábban viszonylag homogén és földrajzilag nem túl távoli gazdasági terek egybeszervezése jelentette a területfejlesztési feladatot (az olasz Mezzogiorno, néhány francia és nyugatnémet rurális térség volt a regionális politika akcióterülete), a ,,Kilencek”, majd a ,Tizenkettek” a regionális különbségek olyan méreteit produkálták, hogy a 70-es évek közepétôl új regionális politikát és intézményrendszert kellett kidolgozni. A regionális politika a Közösség fontos feladatává vált, s ez tükröződik az alapokmányban is. Az 1957. évi Római Szerzớdés a preambulumban még csak általában tesz arról említést, hogy a tagállamoknak a gazdasági egység megteremtését és a harmonikus fejlesztést az egyes régiók közti különbségek mérséklésével, az elmaradott területek felzárkóztatásával kell összekapcsolni. Az 1987. évi Egységes Európai Okmány 130. cikkelye már részletesen kifejti a regionális politika fốbb elveit és eszközeit:

- az egyes régiók közti eltérések, a megkésett fejlódésbốl fakadó esélykülönbségek mérséklése;

- ennek érdekében összehangolt nemzeti, közösségi gazdaságpolitika és strukturális eszközök kialakítása;

- a Regionális Fejlesztési Alap (a közösség 1975-ben létrehozott területfejlesztési intézménye) feladata, hogy megszüntesse a kirívó regionális aránytalanságokat, s elôsegítse a fejlődésben elmaradt régiók felzárkóztatását, valamint a depressziós ipari körzetek újraélesztését;

- a Közösség különbözổ pénzügyi forrásainak koordinálása a hatékony regionális politika érdekében.

Görögország, Spanyolország és Portugália felvételével az EGK-ban a foglalkoztatottak száma és a hazai össztermék 13\%-kal, a népességszám 18\%-kal, a munkanélküliek száma 30\%-kal, a közösség területe és agrárnépessége $36 \%$-kal növekedett. A fejlődésben visszamaradt térségekben élố népesség aránya megduplázódott, a Tizenkettek lakosságának az egyötöde olyan körzetben él, ahol az egy fổre jutó GDP a közösségi átlag (1985-ben 12189 ECU) 75\%-a alatt marad, egy újabb harmada pedig nem éri el az átlagot. A tagállamokon belüli területi különbségeket jelzi egyébként, hogy Dánia kivételével minden országban van átlag alatti jövedelmú körzet; Spanyolország, Portugália, Görögország és Írország valamennyi területi egysége ebbe a kategóriába tartozik (1. táblázat).

Tekintélyes aránytalanságok jellemzik a régiók foglalkoztatási viszonyait is. A Közös Piac 24 régiójában (ezekben él az össznépesség 15,9\%-a) a munkanélküliség az átlagot (1986-ban $10,8 \%$ ) 50\%-kal meghaladja. Magas - közösségi átlag feletti - munkanélküliséget mutató régiókban az EGK-népesség 40,1\%-a él. 
Horváth Gyula: Az európai integráció és a területi együttmüködések hatása a piacgazdaságok regionális politikájára. Tér és Társadalom, 5. 1991. 4. 51-68. p.

TÉT 1991.4

Az európai integráció

53

\section{TÁBLÁZAT}

A jövedelem szóródása az EGK-régiókban, 1985

$(E G K-12=100)$

(Dispersion of incomes in EEC regions, 1985)

\begin{tabular}{|c|c|c|c|c|c|}
\hline \multirow[b]{2}{*}{ 1. Tagállam } & \multicolumn{2}{|c|}{ 2. A legmagasabb } & \multicolumn{2}{|c|}{ 4. A legalacsonyabb } & \multirow{2}{*}{$\begin{array}{l}\text { 6. Országo } \\
\text { átlag }\end{array}$} \\
\hline & $\begin{array}{l}\text { egy fồre } \\
\text { megnevezés }\end{array}$ & $\begin{array}{l}\text { GDP-t be } \\
\text { 3. értéke }\end{array}$ & $\begin{array}{l}\text { tatáó körzet } \\
\text { megnevezés }\end{array}$ & 5. értéke & \\
\hline NSZK & Hamburga) & 195,5 & Lüneburg & 79,3 & 120,6 \\
\hline Franciaország & lle de France ${ }^{\text {b) }}$ & 159,4 & Korzika & 73,0 & 113,1 \\
\hline Olaszország & Valle d'Aostac) & 137,0 & Calabria & 54,4 & 91,4 \\
\hline Hollandia & Észak-Hollandiad) & 121,4 & Friesland & 82,4 & 105,0 \\
\hline Belgium & Antwerpen megye & 130,8 & Hainaut & 80,9 & 109,2 \\
\hline Luxemburg & - & - & - & - & 128,3 \\
\hline Nagy-Britannia & Nagy Londone) & 155,1 & Staffordshire & 85,7 & 101,7 \\
\hline Írország & - & - & - & - & 70,1 \\
\hline Dánia & Fôvárosi régió & 142,9 & Keleti régió & 111,6 & 125,0 \\
\hline Görögország & Anatolia Stereas & 61,4 & Trákia & 43,2 & 56,6 \\
\hline Spanyolország & Baleári szigetek $^{\mathrm{f})}$ & 97,5 & Extremadura & 46,6 & 77,4 \\
\hline Portugália & - & - & - & - & 50,5 \\
\hline Összeseng) & & 140 & & 60 & \\
\hline
\end{tabular}

Forrás: Terza relazione periodica ... alapján saját számítások.

Megyjegyzések: a) Második a darmstadti körzet $(150,4)$

b) Második Felsô-Normandia (117,0)

c) Második Lombardia $(119,0)$

d) A groningeni körzet $(237,4)$ kivételével, ahol a jövedelem kb. felét a földgázkitermelés adja.

e) Második Grampian $(\mathbf{1 2 8 , 6})$

f) Második a Baszkföld $(95,6)$

g) A legmagasabb és legalacsonyabb 25 régió átlaga

1. Member country

2. Name of region with highert GDP per capita

3. Value of region with highest GDP per capita
4. Name of region with lowest GDP per capita

5. Value of region with lowest GDP per capita

6. National average

A jövedelmi viszonyokhoz hasonlóan a legkedvezốtlenebb pozícióban a közösség mediterrán szárnya van. Spanyolország helyzete többszörösen is súlyos: nincs olyan tartomány, amely átlag alatti munkanélküliséget mutatna, itt található a Közös Piac legmagasabb munkanélküliségi rátájú régiója (Andalúziában közel 1 millió ember keres munkát), s különösen magas a fiatal korosztály munkanélküliségi mutatója (Spanyolországban minden második, Dél-Olaszországban minden harmadik 18-25 év közti fiatal munkanélküli). Görögország helyzete azért sajátos (tartományaiban a munkanélküliség nem éri el a közösségi átlagot), mert ebben az országban még nem indultak be jelentốs szerkezetátalakítási programok, s a mezôgazdasági alulfoglalkoztatottság miatt kapunk , kedvezô” értékeket (1. ábra). 


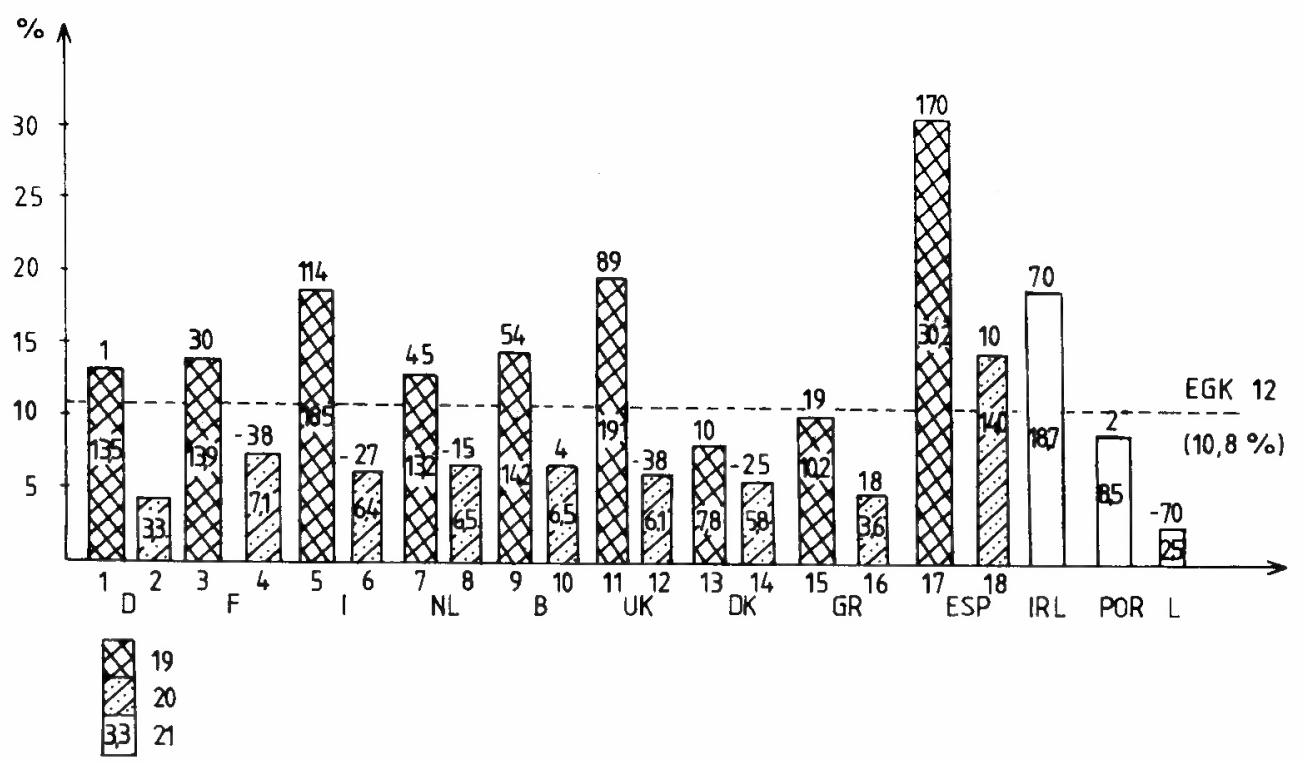

1. ÁBRA

A munkanélküliség regionális szélsó értékei az EGK országaiban, 1985

(Regional extreme values of unemployment in EEC countries, 1985)

1. Bréma, 2. Stuttgart, 3. Lanquedoc-Rousillon, 4. Elzász, 5. Basilicata, 6. Trentino-Alto Adige, 7. Groningen, 8. Zeeland, 9. Hainaut, 10. Nyugat-Flandria, 11. Merseyside, 12. Berkeshire-Oxfordshire, 13. Keleti régió, 14. Fốvárosi körzet, 15. Anatolia Stereas, 16. Trákia, 17. Andalúzia, 18. Galícia 19. A legmagasabb munkanélküliséget mutató terület. 20. A legalacsonyabb munkanélküliséget mutató terület. 21. A munkanélküliségi ráta változása 1981-1985(\%)

A gazdasági teljesítốképesség és a foglalkoztatottság alakulását elsổsorban a térségek gazdasági struktúrája határozza meg, a régiók belsỗ szerkezeti adottságai lényeges eltéréseket mutatnak. Az iparilag fejlett tagországokban a posztindusztriális társadalom gazdasági szerkezete jellemzi a térségeket (a mezôgazdasági foglalkoztatottak aránya 4-8\% között mozog, s 50\% körüli vagy afölötti a tercier ágazatokban dolgozók aránya), a dél-európai országokban (a Mezzogiornót is ide számítva) az agrárágazatnak még mindig meghatározó súlya van számos régióban. Spanyolország 17 tartománya közül 12-ben a mezőgazdasági foglalkoztatottak aránya $20 \%$ fölött van (Galiciában 46,2\%, Extremadurában 34,9\%), Görögországban pedig három körzetben meghaladja az 50\%-ot, és a dél-olasz régiókban is $20 \%$ feletti értékeket találunk.

Ejövedelmi és válságfaktorok a fejlổoőképességet csak részlegesen érzékeltetik, a közös piaci regionális politikai gyakorlatban az ún. szintetikus indexet használják az egyes régiók teljesítôképességének a mérésére. (Az index számításának módját nem ismertetjük részletesen, csupán annyit jegyzünk meg, hogy az egy lakosra és az egy foglalkoztatottra jutó GDP 25-25\%-os, a munkanélküliségi mutató - korrigálva a mezốgazdasági alulfoglal koztatottsággal - 40\%-os, és a prognosztizált új munkaerôszükséglet 10\%-os súllyal szerepel a kalkulációban.) A szintetikus index alapján 1985-ben a Közösség tíz legelmaradottabb térsége a következố 
volt (zárójelben az ország és az index értéke): Basilicata (I: 37,1), Calabria (I: 38,0), Andalúzia (ESP: 38,4), Extremadura (ESP: 38,9), Kanári szigetek (ESP: 45,7), Írország (47,8), Szardínia (I: 49,2), Castilla Mancha (ESP: 49,5), Molise (I: 50,6) és Murchia (ESP: 50,9). A legmagasabb értékeket az alábbi térségek mutatták: Darmstadti körzet (D: 172,8), Felsõ-Bajorország (D: 167,1), Stuttgarti körzet (D: 162,3), lle de France (F: 154,7), Karlsruhei körzet (D: 152,9), Rajna-Hessen-Pfalz (D: 144,6), Luxemburg (142,8), Valle d'Aosta (I: 142,1), Nyugat-Berlin (D: 141,9), Fớvárosi régió (DK: 141,8). A Közösség népességének 25,7\%-a él olyan térségekben, amelyek szintetikus indexe a közösségi átlag 67\%-a alatt van, és 16,8\%-a olyan térségekben, ahol az index 67 és $100 \%$ között van. A legalsó sávban (36 tartomány tartozik ide) van valamennyi spanyol, portugál és görög körzet, valamint mind a nyolc délolasz régió, s csak egyetlen északi körzet (Észak-Írország) található itt.

\section{TÁBLÁZAT \\ A Közös Piac problematikus régiótípusai \\ (Problematic regions of EEC)}

\begin{tabular}{|c|c|c|c|c|c|c|c|c|c|}
\hline \multirow{3}{*}{ 10. Régiótípus } & \multirow{3}{*}{\multicolumn{2}{|c|}{$\begin{array}{l}\text { 11. A lehatárolás } \\
\text { kritériuma }\end{array}$}} & \multirow{3}{*}{$\begin{array}{l}\text { 12. Népsú- } \\
\text { rüség } \\
\text { fó } / \mathrm{km}^{2}\end{array}$} & \multicolumn{3}{|c|}{$\begin{array}{l}\text { 13. A foglalkoztatottak } \\
\text { megoszlása, } \%\end{array}$} & \multirow{3}{*}{$\begin{array}{l}\text { 17. Munka- } \\
\text { nélküliségi } \\
\text { ráta, \% }\end{array}$} & \multicolumn{2}{|c|}{$\begin{array}{l}\text { 18. A bruttó regio- } \\
\text { nális termék }\end{array}$} \\
\hline & & & & \multirow{2}{*}{$\begin{array}{l}\text { 14. Pri- } \\
\text { mér }\end{array}$} & \multirow{2}{*}{$\begin{array}{l}\text { 15. Szekun- } \\
\text { der }\end{array}$} & \multirow{2}{*}{$\begin{array}{l}\text { 16. Ter- } \\
\text { cier }\end{array}$} & & $\begin{array}{l}\text { 19. egy } \\
\text { lakosra }\end{array}$ & $\begin{array}{l}\text { 20. egy fog- } \\
\text { lalkoztatottra }\end{array}$ \\
\hline & & & & & & & & \multicolumn{2}{|c|}{$\begin{array}{l}\text { 21. jutór értéke az EGK- } \\
\text { átlagában }\end{array}$} \\
\hline $\begin{array}{l}\text { 1. FEJLETLEN } \\
\text { RÉGIÓ }\end{array}$ & \multicolumn{2}{|c|}{ Az egy fốre jutó GDP } & 80 & 24,2 & 27,5 & 48,3 & 14,0 & 61 & 57 \\
\hline $\begin{array}{l}\text { 2. HANYATLÓ IPARI } \\
\text { RÉGIÓ }\end{array}$ & \multicolumn{2}{|c|}{$\begin{array}{l}\text { Az ipari foglalkoztatottak és a } \\
\text { munkanélküliek arányának } \\
\text { kombinácioja }\end{array}$} & 199 & - & - & - & 14,6 & 95 & - \\
\hline 3. AGRÁRTÉRSÉG & \multicolumn{2}{|c|}{$\begin{array}{l}\text { A mezógazdasági foglalkozta- } \\
\text { tottak aránya }\end{array}$} & 75 & 22,5 & 28,9 & 48,6 & 13,5 & 70 & 71 \\
\hline $\begin{array}{l}\text { 4. MEDITERRÁN } \\
\text { RÉGIÓ }\end{array}$ & \multicolumn{2}{|c|}{$\begin{array}{l}\text { A mezógazdaśági végtermék } \\
\text { több mint } 50 \% \text {-a meghatáro- } \\
\text { zott kertészeti termék }\end{array}$} & 104 & 18,2 & 26,1 & 55,7 & 14,5 & 71 & 75 \\
\hline $\begin{array}{l}\text { 5. PROBLEMATIKUS } \\
\text { NAGYVÁROSI } \\
\text { ÖVEZET }\end{array}$ & \multicolumn{2}{|c|}{$\begin{array}{l}\text { A városi körzet } 35 \% \text {-a ala- } \\
\text { csony növekedést mutat }\end{array}$} & 312 & 2,9 & 36,7 & 60,4 & 16,6 & 83 & - \\
\hline $\begin{array}{l}\text { 6. PERIFÉRIKUS } \\
\text { REGIÓ }\end{array}$ & \multicolumn{2}{|c|}{$\begin{array}{l}\text { Szintetikus index a közösségi } \\
\text { átlag } 78 \% \text {-a alatt van }\end{array}$} & 85 & 18,0 & 30,5 & 51,4 & 14,5 & 74 & 74 \\
\hline 7. SZIGETEK & \multicolumn{2}{|l|}{ Az elhelyezkedés } & 109 & 20,1 & 23,0 & 56,9 & 15,6 & 67 & 74 \\
\hline $\begin{array}{l}\text { 8. HATÁRMENTI } \\
\text { REGIÓ }\end{array}$ & \multicolumn{2}{|c|}{$\begin{array}{l}\text { A tagállamok érintkezó te- } \\
\text { rületei }\end{array}$} & 113 & - & - & - & 11,7 & 99 & - \\
\hline 9. EGK12 összesen & & & 134 & 8,9 & 34,6 & 56,2 & 10,8 & 100 & 100 \\
\hline \multicolumn{2}{|c|}{$\begin{array}{l}\text { 1. Underdeveloped region: GDP per } \\
\text { capita } \\
\text { 2. Declining industrial region: combina- } \\
\text { tion of industrial emplo yees and } \\
\text { unemployed } \\
\text { 3. Agricultural region: Proportion of } \\
\text { agricultural employees } \\
\text { 4. Mediterranean region: More than } 50 \% \\
\text { of agricultural final products is certain } \\
\text { horticultural products }\end{array}$} & \multicolumn{4}{|c|}{$\begin{array}{l}\text { 5. Problematic urban region: } 35 \% \text { of the } \\
\text { urban region shows low increase } \\
\text { 6. Peripheric region: Synthetic index is } \\
\text { below } 78 \% \text { of Community average } \\
\text { 7. Islands: Location } \\
\text { 8. Borderline regions: Frontier regions of } \\
\text { the member contries } \\
\text { 9. EEC } 12 \text { total } \\
\text { 10. Type of region } \\
\text { 11. Criteria of delineation }\end{array}$} & \multicolumn{2}{|c|}{$\begin{array}{l}\text { 12. Population d } \\
\text { 13. Distribution } \\
\text { 14. Primary } \\
\text { 15. Secondary } \\
\text { 16. Tertiary } \\
\text { 17. Unemployme } \\
\text { 18. Gross region } \\
\text { 19. per inhabitan } \\
\text { 20. per employee } \\
\text { 21. in the EEC a }\end{array}$} & $\begin{array}{l}\text { ant rate } \\
\text { al produc } \\
\text { varage }\end{array}$ & $\begin{array}{l}\left.\mathrm{ead} / \mathrm{km}^{2}\right) \\
\text { yees, } \%\end{array}$ \\
\hline
\end{tabular}


A Közösség regionális politikája azonban nem csupán a fejlôdésben elmaradott térségeket vonta hatókörébe; a területi egységek tipizálása komplex társadalmi-gazdasági paraméterek alapján történt, ezért a problematikus régiók több típusával találkozhatunk (2. táblázat). Az egyes régiótípusok sokszor átfedik egymást, bizonyos régiók halmozottan hátrányos helyzetūnek tekinthetốk (így például a leggyengébb teljesítốképességũ régiók nagy részét az 1-3-4-6-8. típusba is besorolhatjuk). Az egyes típusok tagországonkénti elhelyezkedését mutatja a 3. táblázat.

\section{TÁBLÁZAT}

A problematikus régiótípusokban éló népesség aránya, \%

(Proportion of people in problematic regions, \%)

\begin{tabular}{lrrrrrrrr}
\hline \multicolumn{1}{c}{ 1. Tagország } & \multicolumn{1}{c}{ 1. } & \multicolumn{1}{c}{ 2. } & \multicolumn{1}{c}{4.} & \multicolumn{1}{c}{5.} & \multicolumn{1}{c}{6.} & \multicolumn{1}{c}{7.} & \multicolumn{1}{c}{8.} \\
\hline 2. NSZK & 0,0 & 10,4 & 1,7 & 0,0 & 1,8 & 0,0 & 0,1 & 13,1 \\
3. Franciaország & 0,4 & 26,7 & 32,3 & 11,3 & 15,2 & 17,4 & 0,5 & 19,9 \\
4. Olaszország & 36,0 & 11,8 & 40,1 & 46,5 & 16,4 & 42,1 & 11,7 & 5,6 \\
5. Hollandia & 0,0 & 19,1 & 0,0 & 0,0 & 12,5 & 0,0 & 0,1 & 51,5 \\
6. Belgium & 0,0 & 42,1 & 0,0 & 0,0 & 14,1 & 0,0 & 0,0 & 77,5 \\
7. Luxemburg & 0,0 & 0,0 & 0,0 & 0,0 & 0,0 & 0,0 & 0,0 & 100,0 \\
8. Nagy-Britannia & 0,0 & 45,2 & 0,0 & 0,0 & 28,5 & 15,2 & 0,4 & 2,8 \\
9. Írország & 100,0 & 8,5 & 100,0 & 0,0 & 40,0 & 100,0 & 0,3 & 11,5 \\
10. Dánia & 0,0 & 0,0 & 0,0 & 0,0 & 0,0 & 66,3 & 16,0 & 4,9 \\
11. Görögország & 100,0 & 0,0 & 57,7 & 92,4 &.. & 100,0 & 14,7 & 0,0 \\
12. Spanyolország & 45,0 & 36,2 & 64,3 & 39,5 & 24,7 & 100,0 & 4,2 & 17,6 \\
13. Portugália & 100,0 & 0,0 & 100,0 & 0,0 &.. & 100,0 & 5,0 & 22,3 \\
\hline 14. Összesen & 19,2 & 23,2 & 26,7 & 17,8 & 14,8 & 33,5 & 3,5 & 15,2 \\
\hline
\end{tabular}

Forrás: Terza relazione periodica...
1. Member country
5. Holland
2. F.R.G.
6. Belgium
9. Ireland
10. Denmark
13. Portugal
3. France
7. Luxembourg
11. Greece
14. Total
4. Italy
8. Great Britain
12. Spain

\section{A közös regionális politika eszközei}

Az elôbbiekben már említett regionális politikai célok megvalósítását az Európai Közösség külön pénzügyi alapjai szolgálják. A viszonylagos belsố kiegyenlítettség miatt, ahogy már jeleztük, kezdetben a közösségnek nem voltak elkülönített pénzügyi eszközei regionális politikai célokra. A területi feszültségek mérséklésére a strukturális alapok valamelyike (Európai Szociális Alap, Mezôgazdasági Tanácsadó és Szavatoló Alap), illetve az Európai Fejlesztési Bank vagy az Európai Szén- és Acélközösség nyújtott pénzügyi támogatást.

A regionális politikában bekövetkezett fordulat szervezeti következménye volt az Európai Regionális Fejlesztési Alap létrehozása 1975-ben. Az elsố három éves költségvetési periódusban 
Horváth Gyula: Az európai integráció és a területi együttmüködések hatása a piacgazdaságok regionális politikájára. Tér és Társadalom, 5. 1991. 4. 51-68. p.

TÉT $1991 \cdot 4$ Az európai integráció

(1975-1977) 1300 millió ECU, 1989-ben pedig egy esztendőre már 4500 millió ECU állt az Alap rendelkezésére (a három strukturális alapból egyébként 1988-ban kb. 7700 millió ECU-t fordítottak a területfejlesztés finanszírozására. A regionális politika súlyának növekedését mutatja, hogy ez a pénzügyi tétel 1978-ban az EGK-költségvetés 4,3\%-át, 1983-ban 9,4\%-át, 1988-ban 17,1\%-át tette ki).

Az Európai Regionális Fejlesztési Alap 1975-1988 között 24400 millió ECU-t fordított kb. 41 ezer közösségi beruházás finanszírozására. E 14 esztendổ alatt az Alap forrásaiból 900 ezer munkahely létesült Nyugat-Európában. A fejlesztések $84 \%$-a infrastrukturális beruházás volt. A 2a. ábrán látható, hogy az Alapból a legnagyobb összegeket Olaszország és Nagy-Britannia használta fel ebben az idôszakban, bár 1988-ban már Spanyolország a második legjobban támogatott ország (2b. ábra).

A)

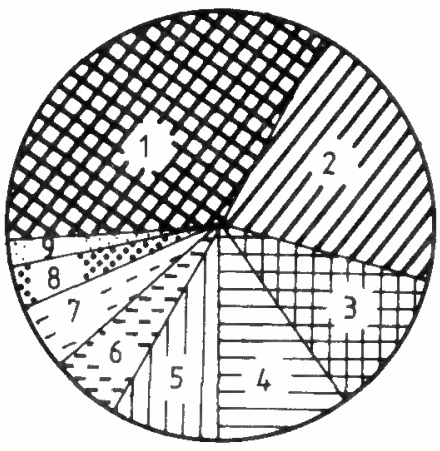

B)

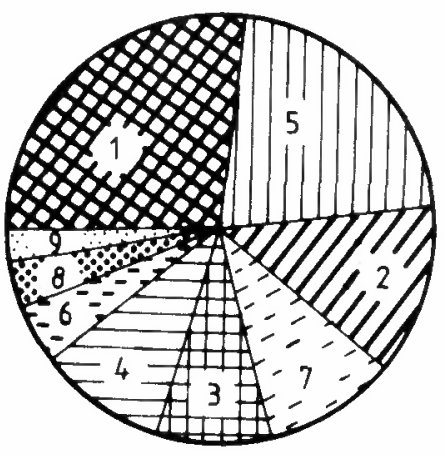

2. ÁBRA

Az Európai Regionális Fejlesztési Alap felhasználása tagországonként (\%)

(Use of European Regional Development Fund by member countries, \%)

$\begin{array}{ll}\text { a) } 1975-1988 & \text { b) } 1988\end{array}$ 
A közösség legfejlettebb régióit leszámítva 1975-1988 között valamennyi körzet részesült Alap-támogatásban. A támogatást elnyert térségek lakóira fejenként 173 ECU jutott. Az olasz Toscana és Basilicata régió 1000 ECU feletti támogatásban részesültek, azonban az olasz Campania, Abruzzi, Molise, Calabria, Szardinia, a görög Kréta, Makedonia és Epirosz, valamint több brit régió viszont 300-1000 ECU támogatást kapott (3. ábra).

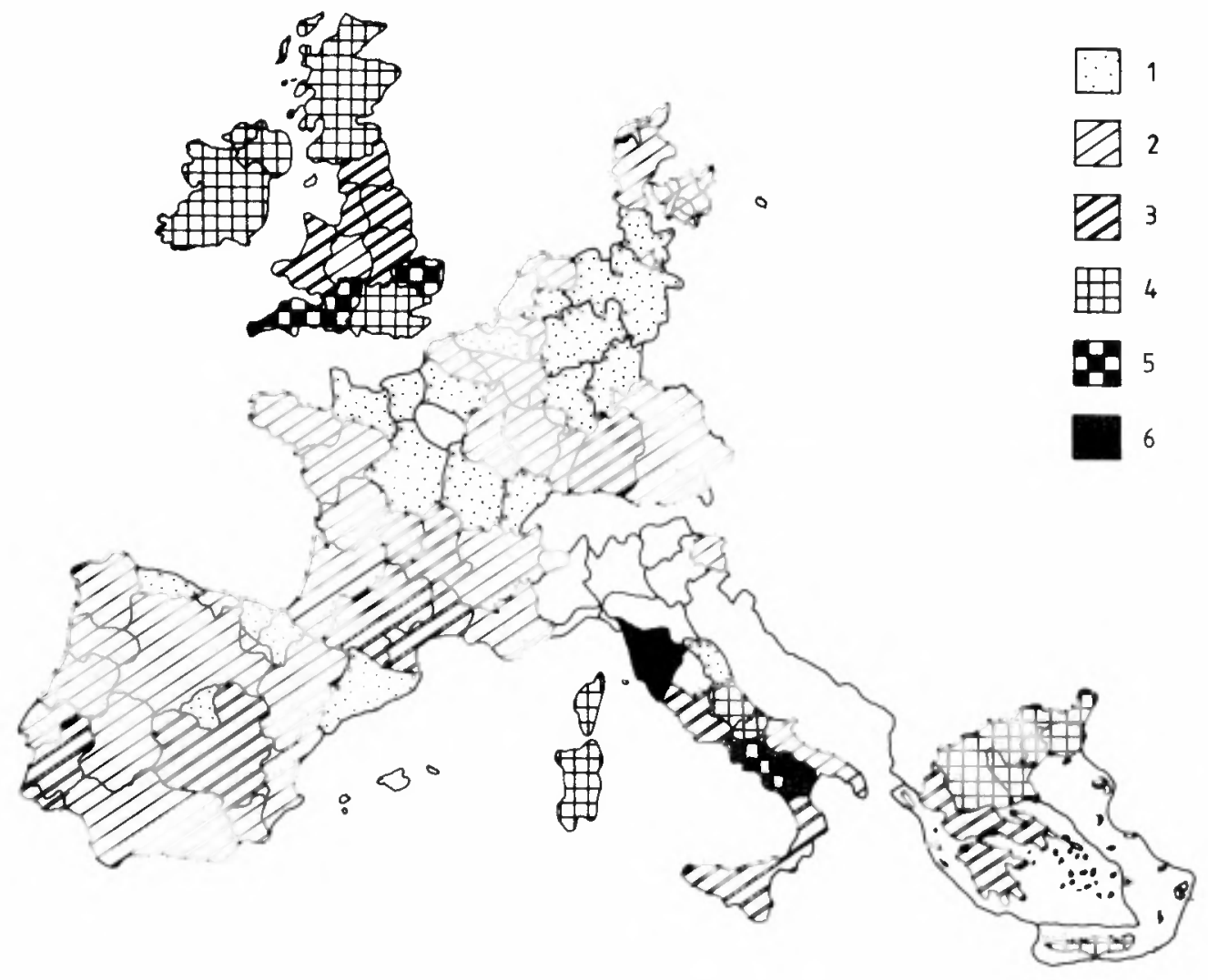

3. ÁBRA

Az Európai Regionális Fejlesztési Alapból folyósitott támogatások egy lakosra jutó összege 1975-1988 között, ECU

(Per capita amount of subsidies granted from the European Regional Development

$1=1-50$

Fund between 1975-1988, ECU)

$2=51-150$

$3=151-300$

$4=301-500$

$5=501-1000$

$6=1001-$ 
Horváth Gyula: Az európai integráció és a területi együttmüködések hatása a piacgazdaságok regionális politikájára. Tér és Társadalom, 5. 1991. 4. 51-68. p.

TÉT $1991 \cdot 4$ Az európai integráció

Az Alap támogatási programjai és az 1988. évi összegek a 4. ábrán láthatók.

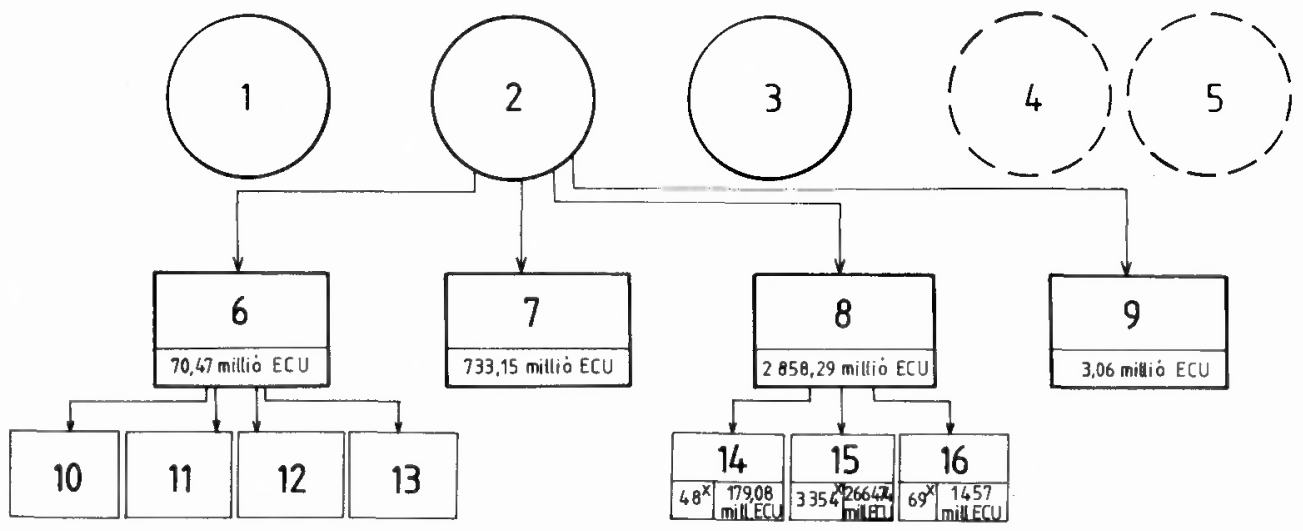

4. ÁBRA

A regionális politika pénzügyi forrásai az EGK-ban, 1988

(Financial resources of regional policy in EEC, 1988)

1 = Európai Szociális Alap (European Social Fund)

2 = Európai Regionális Fejlesztési Alap (European Regional Development Fund)

3 - Európai Mezôgazdasági Tanácsadó és Szavatoló Alap (European Agricultural Guidance and Guarantee Fund)

4 = Európai Szén- és Acélközösség (European Coal and Steel Community)

5 = Európai Fejlesztési Bank (European Development Bank)

6 = Közösségi programok (Community programs)

7 = Közösségi érdekeltségú nemzeti programok (National programs with Community interest)

8 = EGK-projektek (EEC projects)

9 = Tanulmánytervek (Study drafts)

10 = Vaskohászati körzetek szerkezetátalakítása (Restructuring of iron and steel areas)

11 = Hajógyártási körzetek szerkezetátalakítása (Restructuring of shipbuilding regions)

12 = Telekommunikáció fejlesztése (Development of telecommunications)

13 = Helyi energetikai rendszerek fejlesztése (Development of local energetic systems)

14 = Ipar, szolgáltatás, kisipar (Industry, services, small-scale industry)

15 = Infrastruktúra (Infrastructure)

16 = Belső́ potenciál fejlesztése (Development of inner potencials)

Az Európai Egységokmányban rögzített regionális politikai célok, valamint a fejlesztési alapok hasznosításának tapasztalatai alapján — figyelembevéve az 1993-tól érvényes egységes piac követelményeit is - az Európai Közösség Tanácsa 1988. évi határozatában módosította a strukturális alapok, köztük az Európai Regionális Fejlesztési Alap, mứködésének alapelveit. Ennek célja elsốsorban az volt, hogy létrejöhessen köztük a kellố összhang, és felhasználásuk módja célirányosabb legyen. Egyidejứleg döntött az Alap megduplázásáról is. Az elôirányzat szerint 1991-ben 11,6 milliárd ECU, 1992-ben 12,9 milliárd ECU, 1993-ban 14,5 milliárd ECU fordítható területfejlesztési célokra. A reform elsô számú alapelve a pénzügyi eszközök problematikus régiókba való koncentrálása volt. (A 80-as évtized végére benyújtott támogatási pályázatok — nagy számuk miatt - már szinte áttekinthetetlenek voltak, 1988-ban a beérkezett 7976 pályázatból 3 910-et fogadtak el.) 
A határozat öt fejlesztési prioritást jelölt meg:

1. A fejlődésben megkésett területek (ahol az egy fóre jutó bruttó regionális termék a közösségi átlag $75 \%$-a alatt van);

2. Az iparilag hanyatló régiók, határmenti területek, vagy egyéb fontos munkaerô-központok (ahol a munkanélküliségi ráta és az ipari foglalkoztatottak aránya a közösségi átlag felett van, és az ipari foglalkoztatottak száma folyamatosan csökken);

3. Tartósan magas munkanélküliséget mutató területek (ahol a 25 év feletti aktív népesség 12 hónapon túli munkanélkülisége a közösségi átlag feletti);

4. A 25 év alatti fiatalok munkához juttatásának elôsegítése;

5. Az agrártérségek fejlesztése

- a mezốgazdasági termelési szerkezet átalakítása, az agrárpiacok fejlesztése,

- a rurális övezetek fejlesztésének elổmozdítása (ahol magas az agrárfoglalkoztatottak aránya, alacsonyak az agrártermelés jövedelmei és alacsony a térség egy fổre jutó GDP-je is).

Az új struktúrapolitika célrendszerének második alapelve: a közös részvétel és együttmúködés a támogatásban érintett terület szervei, a regionális folyamatok szereplôi, a nemzeti kormányok és a közösség szervezetei között a fejlesztési akció valamennyi fázisában. Mivel a strukturális támogatások kiegészítô jellegũek, hatékonyságukat a térség szereplôinek együttmüködése is befolyásolja. A harmadik alapelv a gazdaságpolitikai stratégiák helyi, regionális és nemzeti összehangolásának szükségességét rögzíti.

\section{A régiók Európájának kihívásai}

Az 1992-ben létrejövố egységes Nyugat-Európában a polgárok szabadon választhatják meg lak6- és munkahelyüket, a turisták hitelkártyáikat az Európai Közösségben mindenütt használhatják majd, a vállalatok új piacokat hódítanak meg. Lehetốvé válik tehát az emberek, a tốke és az áruk szabad áramlása. A Közös Piac tagállamaiban a területi (regionális) kormányzatok már évek óta programszerũen készülnek az ezredforduló nagy kihívására: a nagytájak országhatárokon túlnyúló együttmüködésére és versengésére.

Az elmúlt évtizedekben nem ugyanazok a régiók emelkedtek a fejlôdés élvonalába, amelyek a korábbi iparosítási szakasz vezetô tartományai voltak. A tókés ipar évszázados fellegvárai (Délkelet-Anglia, Vallónia, Lotharingia, a Ruhr vidék) indultak hanyatlásnak és eddig szinte ismeretlen vidékek (Baden-Württemberg, Katalónia, Bajorország, Közép-Olaszország) haladtak egyre feljebb az európai régiók fejlettségi rangsorában. Gyors fejlốdésükben fontos szerepet játszottak .zok a regionális fejlesztési programok, amelyeket a regionális kormányzatok - nem egyszer a központi szervek ellenállásával szemben — dolgoztak ki. A regionális hatalom mozgástere ekkor már jelentôsen kibỗvült Nyugat-Európában. Az európai identitás megteremtése mellett a regionalizmus lett a második világháború utáni Nyugat-Európa politikai és gazdasági fejlởdésének meghatározó dinamizáló tényezôje. A regionalizmus impulzív erổvé fejlődésének, véleményem szerint, négy fổ oka volt:

1. A modern állam technikai szükségletei. A területrendezési és -fejlesztési tervezés követelményeit a nagy területi egységek elégítették ki, de ez volt a megfelelô színtér az ágazati érdekellentétek harmonizálásához is. A központi hatalom nem egyszer (pl. Franciaországban és Nagy- 
Horváth Gyula: Az európai integráció és a területi együttmüködések hatása a piacgazdaságok regionális politikájára. Tér és Társadalom, 5. 1991. 4. 51-68. p.

TÉT 1991.4

Az európai integráció

Britanniában) saját túlterhelésének mérséklése érdekében hozott létre regionális szerveket és delegált ezekhez jogosítványokat.

2. A regionális-interregionális politika jellege. A keynesianus regionális gazdaságpolitika alapvetốen centralizált eszközökkel operált, ezek alkalmazásához a fenti indok alapján kialakított tervezési körzetek hatékonynak bizonyultak.

3. Regionális kulturális és gazdasági igények. Nyugat-Európában különbözô regionális érdekcsoportok léptek fel a modern kapitalizmus következményei - többnyire a gazdasági hanyatlás - ellen vagy régiójuk modernizálása érdekében. Mind a , hagyományốrzô’, mind pedig a modernizációs erók saját gazdaságfilozófiát vetettek be a központi gazdaságpolitika ellen, s ezt igyekeztek is intézményesíteni. A regionális stratégiák meghatározó szereplői lettek a különbözó pénzintézetek, fejlesztési társaságok, szövetségek, alapítványok, ügynökségek. Feladatuk a térségek társadalmi-gazdasági fejlesztési programjainak támogatása, pénzügyi finanszírozása, tanácsadás és információszolgáltatás.

4. A regionális önrendelkezési mozgalmak kibontakozása. Az etnoregionalizmus tér-és hatalomszervezõ erejével korábban a modern nyugati nemzetállamoknak, majd pedig az európai integráció szupranacionális szerveinek számolniuk kellett. A kisebbségi mozgalmak fontos szerepet játszottak a Nyugat-Európát ma már átszövố interregionális, határmenti kapcsolatok kialakításában és a régiók Európája politikai irányvonalának kidolgozásában.

E tényezốk kölcsönhatásának - valamint más gazdasági és politikai változások - eredményeképpen az utóbbi két évtizedben Nyugat-Európában decentralizálódott a politikai és a gazdasági hatalom. A nagy gazdasági potenciállal rendelkezô területi egységek tehát a régiók versenyében jó adottságokkal startolhatnak, a szuverenitás felosztásáért a központi hatalommal folytatott eredményes küzdelemben a konkurrenciaharc számos módszerét is elsajátíthatták.

A nyugat-európai régiók fejlôdési pályảinak az elemzéséból arra a következtetésre juthatunk, hogy az ezredfordulóra az európai gazdasági erố súlypontja az észak-francia — benelux — nyugatnémet háromszögtốl - Magyarország számára kedvezô módon - keletebbre, a dél-német és az észak-olasz tartományok irányába tolódik át. A metropolis-agglomerációkra felfüzött észak-nyugat európai gazdasági tömörülésben a hagyományos növekedési erôforrások kimerülốben vannak, míg az Alpok környéki régiók fejlôdésében az új növekedési tényezók játsszák a fổ szerepet, s a modern struktúrák meghonosítását kevésbé akadályozzák a tradicionális ágazati, szervezeti és települési szerkezetek inerciális erői. A két regionális rendszer gazdasági teljesítốképességében már ma sincsenek lényeges különbségek, bár némely mutató a történelmi erơközpont minốségi elốnyét jelzi.

Nem véletlen tehát, hogy az Alpok-régiók - alaposan átgondolván fejlôdési lehetőségeiket - nagy intenzitással fogtak hozzá új integrációs erốvonalak kialakításához. A középeurópai államok tartományai a 70-es évek eleje óta több területi együttmúkỏdési társulást alapítottak. 1972-ben jött létre a Nemzetközi Bodeni-tó Konferencia (tagja hat osztrák, nyugatnémet és svájci tartomány), ezzel egyidóben 10 osztrák, svájci, nyugatnémet és olasz tartomány megszervezte az Alpok Munkaközösséget. 1978-ban alakult meg az Alpok-Adria Munkaközösség, majd 1990-ben a Duna Menti Országok Munkaközössége.

E különbözô, sok szálon futó, de ma még alapvetően konzultációs, s kevésbé gazdasági kooperációs együttmúködési programok legaktívabb kezdeményezóje a Bajor Szabad Állam. Integrátori szerepvállalását elsôsorban gazdasági szempontok motiválják. A hagyományosan 
erốs német gazdasági befolyás folytonosságának az a biztosítéka, hogy a technológiaintenzív növekedési pályán lassúbb ütemben elổehaladó Nyugat-Európa húzógazdasága továbbra is az NSZK. Benne a bajor gazdaság (s az utóbbi idốben a Baden-Württemberg-i is) területi növekedési centrummá való fejlôdését pragmatikusan a közép-európai együttmúködésre is alapozza. Ennek tartalmát a gazdaság, a vállalati szerkezet és a technológia modernizálásában, formáját pedig a közigazgatási egységek közötti regionális együttmúködésben fogalmazza meg. Ez a regionális alapokon nyugvó külpiaci stratégia már számol azzal is, hogy az Európai Közösség egységes belpiaci programja regionális piaci átrendezổdéshez, területi újradifferenciálódáshoz vezet. Bajorország mellett az utóbbi idốben expanzív külgazdasági szervezổmunkába fogtak az észak-olasz régiók. Lombardia és Friuli-Venezia Giulia tartományok kezdeményezései lendítették meg a közép-európai regionális együttmüködést. Lombardia aktív szerepet játszott emellett az ún. ,,4 Motorikus Régió” szövetség megalakításában is. Baden-Württemberg, Katalónia, Lombardia és a Rhone-Alpok régió közös program alapján szervezi a gazdaság szerkezeti átalakítását, a kutatásintenzív csúcstechnológiák meghonosítását a termelésben.

A regionális fejlổdésben megmutatkozó különbségek, a növekedési pólusok vándorlása, a korszakonként eltérổ területfejlesztési minták és modellek követése mindig is versenyszituációt eredményeztek a régiók között. Az 1992. után létrejövő piacon a régiók gazdaságainak értékesítési lehetôségei ugyan kedvezốbbek lesznek, de mindez a konkurrenciára is érvényes lesz. Ez az alapvetô oka annak, hogy már ma oly sok nyugat-európai vállalat (nem egyszer állami vagy regionális kormányzati segítséggel) lép fúzióra más országbeli vállalatokkal. Az európai integráció lényeges ismérve lesz a régiók és a vállalatok közötti kölcsönhatások erôsödése, ami egyidejứleg kiélezi a versenyt, de a régiók és a vállalatok kooperációját is.

A régiók együttmúködési hajlamait mindenekelôtt gazdasági szerkezetük azonossága, szerkezetátalakítási törekvéseik hasonlósága, valamint a földrajzi közelség, a határ menti fekvés alakítja.

A hasonló szerkezeti problémákkal küszködô területek, az ún. depressziós vagy régi iparvidékek gazdasági fellendítésében a régiók közötti együttmüködés már eddig is szerepet játszott. A francia, a belga és a nyugatnémet nehézipari körzetek kooperációs programjai, a depressziós régiók európai szövetségének akciói érzékelhetô eredményekhez vezettek e térségek gazdasági aktivitásának újraélesztésében, az Európai Közösség regionális politikájának alakításában. E térségek regionális kormányzatai az 1992. utáni piaci kihívásokra külgazdasági stratégiájuk újrafogalmazásával is készülnek reagálni. A belga Vallónia kormánya például már meghatározta azokat az európai régiókat, impulziós-beavatkozási területeket (Spanyolországban Katalónia, Olaszországban Veneto, Magyarországon Baranya megye), amelyekkel szoros gazdasági együttmúködést kíván kiépíteni.

Az érdekazonossággal jellemezhetô másik régiócsoportot a határmenti tartományok alkotják. A közös piaci eszme - mint ahogy említettem, sokszor regionális politikai mozgalmak nyomására - az interregionális kapcsolatok fejlesztésére mindig nagy hangsúlyt fektetett. A gyakran nemzetiségileg vegyes lakosságú, történelmi-kulturális vagy gazdasági rokon vonásokat mutató tájegységek erôforrásainak együttes felhasználása a közösségi politika preferált területe. Az elmúlt másfél évtizedben sokrétú ipari és kereskedelmi együttmứködés bontakozott ki a nyugat-európai határmenti térségekben, közös infrastrukturális és környezetvédelmi programok születtek, mindennapossá és tömegméretưvé váltak a személyes és az intézményes kap- 
Horváth Gyula: Az európai integráció és a területi együttmüködések hatása a piacgazdaságok regionális politikájára. Tér és Társadalom, 5. 1991. 4. 51-68. p.

TÉT 1991.4

Az európai integráció

csolatok, amelyek kibontakozását - az évtizedekre visszanyúló általános liberális határátlépési rendszeren túlmenổen - néhány ország külön belsổ jogi és politikai intézményekkel is támogatta. 1980-ban az Európa Tanács madridi miniszteri értekezletén keretmegállapodást írtak alá a határokon túli együttmúködések decentralizálásáról. E megállapodás értelmében a helyi és a területi kormányzatok jogosultak önálló nemzetközi kapcsolatok felvételére és alakítására, amely e közösségek belsở területi politikájának természetes meghosszabbítása.

Míg az elóbb említett területeken alapvetốen a régiók érdekazonosságai domináltak, addig a piaci expanziós kényszer az érdekellentétek szaporodását váltja majd ki. Sok nyugat-európai nagyváros már megkezdte a felkészülést az európai polgárok és vállalatok kegyéért folytatandó jövốbeli konkurrenciaharcra.

Egy közös piaci kutatócsoport összehasonlította a tagországok, valamint Ausztria és Svájc 200 ezer fốnél népesebb városait azon az alapon, hogy mennyiben felelnek meg 16 kritériumnak (a városok nemzetközi tekintélyét és dinamizmusát — többek között — azzal mérték, hogy hány nemzetközi cég és képviselet mứködik ott, hány kutató dolgozik az egyetemeken és a kutatóintézetekben, milyen forgalmat bonyolít le a város repülốtere, hány vásárt és nemzetközi kongresszust, rendezvényt fogad be évente). A rangsor legelején a nagy európai fốvárosok állnak, majd az egyes országok fejlett politikai és gazdasági , társközpontjai” (pl. Milánó, Barcelona, Marseille) következnek. A regionális központok versenypozíciói lényeges eltéréseket mutatnak. Érdekes - s minden bizonnyal várospolitikai és -stratégiai okokkal magyarázható - eredmény, hogy a nemzetközi befektetési piacokon eddig kevésbé jegyzett városok (Trieszt, Modena, Bologna, Utrecht, Montpellier, Augsburg, Graz) elókeló helyezést értek el.

A nyugat-európai városoknak - valamint hamarosan a magyar nagyvárosoknak is - fejlesztési stratégiájuk kialakításában számolniuk kell azzal, hogy:

- a gazdasági növekedés determinánsai között elsố helyre kerül a lakóhely minốsége, a város kulturális-tudományos miliôje, a lakókörnyezet kedvezó állapota;

— nố az európai városok közötti kapcsolatok intenzitása, fokozódik a városok elérhetốségének és megközelíthetôségének a szerepe;

- a nemzetközi piacokon felértékelổnek a komplex kínálattal jelentkezố és ezt megfelelốen menedzselni képes városok;

- a nemzeti kormányok befolyása csökken, és növekszik a regionális kormányzatok, valamint a szupranacionális európai intézmények jelentôsége.

A hagyományos európai regionális tömörülésben - azért, mert fejlődésének csúcspontja a nemzetállamok makroszintú együttmúkködése kiteljesedésének az idejére esett, s ezt a kooperációt nemzetek feletti szervezetek inspirálták - sokoldalú regionális együttmúködési szervezödések nem fejlốdtek ki. A területközi együttmûködés e térségben kialakult két formája a határmenti régiók kooperációja és az azonos fejlơdési problémákkal küszködô, térben egymástól távoli régiók laza, informális szövetsége.

A közép-európai tömörülés az elóbbi két együttmüködési formản kívül az európai integráció sajátos modellkísérletét indította el 1978-ban. Az ekkor megalakult Alpok-Adria Munkaközösségnek ma tizennyolc olasz, osztrák, német, szlovén, horvát, magyar és svájci tagtartománya van.

Az Alpok-Adria Munkaközösség Közép-Európa 38 millió lakosú preintegrációs tömörülése. Akár a humán, akár a gazdasági erôforrásokat nézzük, a Munkaközösségben Olaszország és 
Horváth Gyula: Az európai integráció és a területi együttmüködések hatása a piacgazdaságok regionális politikájára. Tér és Társadalom, 5. 1991. 4. 51-68. p.

64 Horvaith Gyula

TÉT 1991-4

az NSZK pozíciói a meghatározóak. A tagtartományok gazdasági potenciálja, valamint a fajlagos mutatók jelentős regionális különbségeket mutatnak. Bár a keleti tagtartományok.országaik viszonylag fejlettebb területei közé sorolhatók, az egy fơre jutó bruttó regionális termékmutatóik a munkaközösségi átlag felét-harmadát teszik ki. A közösség regionális egységei gazdasági szerkezetének kompetitivitása és komparativitása is nagyfokú eltéréseket tükröz. A magterületek ágazati szerkezetére már a posztindusztriális társadalom gazdasági struktúrája a jellemzó (a tercier ágazatok részesedése a bruttó regionális termék közel vagy több mint $50 \%$-át adja, a modernizáció elốtt álló keleti tartományokban (Burgenlandban is) $40 \%$ alatt marad. A perifériákon magas az agrártermelés aránya.

Az Alpok-Adria Munkaközösség mũködésének elsô évtizedében jobbára az információcserét, a vonalas infrastruktúrák összehangolását (mindenekelốtt az olasz-osztrák-szlovén határmenti háromszögben), valamint a kulturális kapcsolatok szervezését fogta át. Az utóbbi esztendốkben azonban - részint a kelet-európai változások, részint pedig az olasz régiók tốkeexpanziójának köszönhetôen - rendszeressé váltak a tagtartományok gazdasági szervezeteinek tapasztalatcseréi. A gazdasági együttmúködés csírái 1989-90-ben jelentek meg, ebben az idôszakban a lombardiai régió látta el a munkaközösség koordinációs központjának szerepkörét. 1990-ben több olyan program indult, amelyek eredményeképpen megerốsödhetnek a térség integrációs vonásai, s ezek elônnyeit nem csupán a munkaközösség gazdaságilag fejlett tagtartományai élvezhetik, hanem a periférikus keleti tartományok is impulzusokhoz juthatnak gazdasági szerkezetük átalakításában. A tényleges integrációhoz azonban megfelelố intézményekre és eszközökre van szükség. Az egyik együttmúködési program két fontos intézmény megszervezését, a gazdasági integráció kialakításának előfeltételét jelentổ közös regionális fejlesztési alap, és egy közös pénzintézet, felállítását kívánja megalapozni. Ezek az intézmények a közös piaci normák alapján, részben az Európai Közösség pénzügyi forrásaira is támaszkodva hozzájárulhatnának a keleti térségek európai integrációhoz való csatlakozásához.

\section{Összegzés}

Az Európai Közösség másfél évtizedes intenzív regionális politikája nyomán Nyugat- és DélEurópa korábban félperiférikus térségei bẹkapcsolódhattak az európai területi munkamegosztásba, a perifériák pedig esélyt kaptak az integrálódásra. Kiépült a regionális politika múködtetésének területi intézményi hálózata is, amely nem elhanyagolható szerepet játszott az Európai Közösség belsổ kohéziójának erổsítésében, nevezetesen azáltal, hogy a közös piaci eszme nem csupán a központi kormányzat múkködésének volt alapelve, hanem annak fejlesztésében a területi hatalom utóbbi évtizedében egyre inkább megerôsödött bázisai közvetlenül is részt vehettek. E participáció - azon kívül, hogy megalapozta az 1992 utáni régiók Európájának politikai szlogenjét - a nemzetközi területi munkamegosztás elmélyülése révén közvetlen gazdasági elốnyökkel is járt.

A Közösséghez a jövốben csatlakozó államok számára a tagság területfejlesztési szempontból - kétség kívül - pozitív következményekkel járhat majd. Bár ma még nincsenek egzakt összehasonlítható adataink a kelet-közép-európai országok - köztük hazánk - területi jövedelmi 
Horváth Gyula: Az európai integráció és a területi együttmüködések hatása a piacgazdaságok regionális politikájára. Tér és Társadalom, 5. 1991. 4. 51-68. p.

TÉT 1991 = 4

Az európai integráció

65

viszonyairól, a jövốben prognosztizálható területi feszültségek hosszabb távú megoldásában a közös regionális politikai eszközök pótolhatatlan szerepet játszhatnak. Figyelembe véve a Közösségbe késóbb belépett tagállamok tapasztalatait is, az integrációhoz való csatlakozáshoz a felkészülést Magyarországon is meg kell kezdeni.

1. Az új regionális fejlesztési stratégiát a közös piaci alapelvekre építve kell kidolgozni.

2. Végre kell hajtani a területi statisztika reformját, új, többszintủ területi információs rendszert kell kialakítani, majd el kell végezni az összehasonlító vizsgálatokat, hogy meghatározhassuk a magyar vidékek majdani pozícióit az európai régiók rangsorában. A területi fejlốdési folyamatok elemzésében a hazai átlagadatok mellett a jövốben az EGK-régiókhoz való viszonyítást is gyakorlattá kell tenni.

3. A magyar területi közigazgatási egységekben és a nemzetkőzi munkamegosztásban a jövốben érdekeltté váló városi önkormányzatokban ki kell építeni a közösségi politika monitoring rendszerét.

4. A regionális centrumokban meg kell teremteni a közösségi dokumentációs bázisokat és a közösségi információs rendszerekhez illeszkedô központokat.

5. Noha a különbözô nemzetközi szervezetek regionális politikai ajánlásait a korábbi magyar területfejlesztési dokumentumok is - elvi követelményként - figyelembe vették, érvényesítésükre a gazdaságpolitikai gyakorlatban az elvek megvalósítását szolgáló eszközök hiányában nem kerülhetett sor. A nyugat-európai nemzeti és közösségi regionális politikák végrehajtásához anyagi eszközök állnak rendelkezésre. Számításaim szerint a hagyományosan aktív regionális politikát folytató országokban (Belgium, Hollandia, Nagy-Britannia, Írország, Olaszország) a regionális fejlesztési ráfordítások a bruttó hazai termék $0,1-0,3 \%$-át teszik ki. Ehhez a Közös Piac strukturális alapjaiból jóval jelentékenyebb hozzájárulás társul (4. táblázat).

\section{TÁBLÁZAT}

A regionális támogatások alakulása az EGK országokban, 1987

(Regional subsidies in EEC-member countries, 1987)

\begin{tabular}{|c|c|c|c|c|}
\hline 1. Ország & $\begin{array}{l}\text { 2. A támogatott te- } \\
\text { riletek népessége, } \\
\text { ezer fó }\end{array}$ & $\begin{array}{l}\text { 3. Az ország népes- } \\
\text { ségének \%-ában }\end{array}$ & $\begin{array}{l}\text { 4. Az EGK strukturá- } \\
\text { lis alapjaiból nyújtott } \\
\text { támogatás, } \\
\text { ECU/fớ }\end{array}$ & $\begin{array}{l}\text { 5. A nemzeti regioná- } \\
\text { lis programokból } \\
\text { nyújtott támogatás, } \\
\text { ECU/fô, } 1985\end{array}$ \\
\hline 6. NSZK & 11508 & 18,9 & 37,6 & 10,2 \\
\hline Franciaország & 15849 & 28,7 & 62,0 & 4,2 \\
\hline Olaszország & 27086 & 47,5 & 65,4 & 59,8 \\
\hline Hollandia & 1879 & 14,0 & 60,5 & 14,1 \\
\hline Belgium & 2444 & 24,8 & 42,6 & 10,6 \\
\hline Luxemburg & 143 & 37,0 & 63,6 & 9,1 \\
\hline Nagy-Britannia & 21340 & 37,7 & 67,9 & 25,2 \\
\hline Írország & 3508 & 100,0 & 145,2 & 24,1 \\
\hline Dánia & 359 & 7,0 & 42,6 & 10,6 \\
\hline Görögország & 6397 & 70,4 & .. & 95,4 \\
\hline Spanyolország & 31823 & 82,0 & .. & 40,0 \\
\hline Portugália & 10158 & 100,0 & .. & 95,4 \\
\hline
\end{tabular}

Forrás: Ginderachter, J. (1989) Yuill, A. - Allen, K. - Bachtler, J. (1988) alapján saját számítás.

1. Country 4. Subsidy from EEC structural funds, ECU per capita

2. Population of subsidized regions, 1000 people 5. Subsidy from national regional programs, ECU percapita, 1985

3. In the percentage of the country's population 6. Same as Table 3. 
Nem egy esetben a támogatott területek fejlesztésére összességében a GDP 1,0-1,5\%-a jut. (Ez a részesedés egyébként a telekommunikáció fejlesztésére fordított pénzügyi eszközök arányával egyenlố.) S noha - a költségvetési megszorítások miatt - a nemzeti regionális ösztönzési eszközök mennyisége a 80-as évtized eleje óta csökken vagy változatlan maradt, a Közös Piac strukturális alapjaiból nyújtott támogatás mennyisége emelkedik (az Európai Regionális Fejlesztési Alap 1987-ben 7,2 milliárd ECU-vel, 1989-ben 9,0 milliárd ECU-vel, 1990-ben 10,3 milliárd ECU-vel gazdálkodott, az egységes Közös Piacban 1993-ban pedig már 14,5 milliárd ECU-val számolnak). Erre az idốpontra egységesíteni kívánják a nemzeti regionális politikai ösztönzốk képzésének és felhasználásának az elveit. Az új regionális ösztönzési rendszer jellemzổi a következók lesznek:

- az ösztönzés súlypontjai a korábbi automatikus megoldásokról a diszkrecionális (a támogatást nyújtó szerv döntésétól függố) felhasználás irányába tolódnak el;

- a centralizált ösztönzési rendszereket decentralizált formák váltják fel;

- a tốkeberuházásokra irányuló ösztönzés helyett a munkaerố-orientált ösztönzés válik meghatározóvá, s végül

- fokozatosan növekszik a tercier szféra támogatása, s a kis- és középvállalatok szinte kizárólagosságra tesznek szert.

Az európai regionális kapcsolatok dinamizálására tett kísérletek a politikai deklarációk és a programkészítés világában maradnak mindaddig, amíg azokat a merev hazai szervezeti struktúrákban próbáljuk megvalósítani. A mai magyar megyék betagolódását a tényleges regionális integrációba egyrészt szervezeti-intézményi reformokkal, másrészt pedig külgazdasági (és külpolitikai) jogosítványok területi decentralizálásával kell elôsegíteni. A gazdasági együttmúködéshez, közös vállalatok alapításához menedzserszervezetekre, kereskedôházakra, regionális külkereskedelmi vállalatokra, bankokra és piackutató-marketing szervezetekre van szükség. Nagy fontosságú feladat a helyi-területi szervek érdekeltségének, önálló külkapcsolati lehetôségeinek a megteremtése is, mivel az európai régiók nagy része erổs , ,külpolitikai” autonómiával rendelkeznek.

Ahhoz, hogy az egységesülés felé haladó Európába a magyar gazdaság regionális alapokon betagolódhasson, a regionális politikát olyan irányba kell fejleszteni, az állam és a helyi önkormányzatok és azok területi közösségei között a hatalmat úgy kell megosztani, hogy a modernizációs centrumokhoz való alkalmazkodást ne csupán központi normák befolyásolják, hanem a piaci-konjunkturális jelzésekre autonóm helyi-területi döntésekkel is reagálni lehessen.

Az innovatív területfejlesztési stratégia megvalósításának nem elhanyagolható feltétele az ország területi-közigazgatási berendezkedésének radikális reformja. A mai magyar megyék - gazdasági potenciáljuk, piaci méretük, gazdaságszervezési kompetenciájuk rendkívüli gyengesége miatt - alkalmatlanok arra, hogy a nemzetközi területi munkamegosztásban önálló cselekvési erốteret jelentsenek, a nyugat-európai régiók egyenrangú partnerei legyenek.

A megoldást az ország regionális közigazgatásának a megszervezése, a hatalom decentralizálása jelenti. 
Horváth Gyula: Az európai integráció és a területi együttmüködések hatása a piacgazdaságok regionális politikájára. Tér és Társadalom, 5. 1991. 4. 51-68. p.

TÉT 1991 -4 Az európai integráció

\section{Irodalom}

Begg, I. (1988) The regional dimension of the '1992' proposal, Regional Studies, 2.

Brunet, R. (szerk.) (1989) Les villes ,,europeennes", Datar-Reclus, Paris.

Cappellin, R. (1990) L'internazionalizzazione delle economie di Alpe-Adria e la cooperazione interregionali. Milano, Istituto per gli Studi di Politica Internazionale.

Fondo europeo di sviluppo regionale. Bruxelles, Commissione delle Comunitá Europee, 1990.

Gasparini, M.L. - Scaramella, M. (1986) Societá, economia e territorio nell'Europa Communitaria, Napoli, Istituto Geografico Italiano.

Ginderachter, J. (1989) Die Reform der Strukturfonds, Informationen zur Raumentwicklung, 8-9.

Horváth Gy. (1990) A Dél-Dunántúl külgazdasági stratégiájának alapjai (a nemzetközi munkamegosztás és a regionális politika összefüggésében), Pécs, MTA Regionális Kutatások Központja.

Horváth Gy. (1991) Az európai regionális munkamegosztás és a négiók versenye, Településfejlesztés, 1.

Horváth Gy, (1991) A régiók Európájának kihivásai, Juss, 5.

Horváth Gy. (1991) A Közös Piac regionális politikája és intézményei, Ökonomia, 4.

Horvath Gy. (1991) A regionális gazdaságok együttmüködése Európában, Európa Fórum, 1.

Irmen, E. - Sinz, M. (1989) Zur Wettbewerbsfähigkeit der Regionen in der Europäischen Gemeinschaft, Informationen zur Raumentwicklung, 8-9.

Keeting, M. - Johns, B. (szerk.) (1985) Regions in the European Community, Clarendon Press, Oxford.

Klaassen, L.H. (1989) Entwicklung des europäishen Raumes durch regionalen Zusammenarbeit, Raumordnung und Raumforschung, 1.

Mazzuca, R. (1989) Le politiche regionali della Communitá Economica Europea, G. Giappichelli Editore, Torino. Nam, W. - Nerb, J. (1990) Wettbewerbsfahigkeit ausgewählter EG-Regionen, Ifo-Schnelldienst, 9.

Sinz, M. - Steinle, W.J. (1989) Regionale Wettbewerbsfähigkeit und europäischer Binnenmarket, Raumordnung und Raumforschung, 1.

Terza relazione periodica e lo sviluppo delle regioni della Comunitá, Bruxelles, Commissione delle Comunitá Europee, 1987.

Vademecum sulla riforma dei Fondi strutturali comunitari, Bruxelles, Commisione delle Comunitá Europee.

Yuill, D. - Allen, K. - Bachtler, J. (1988) European Regional Incentives, University of Strathclyde, Glasgow.

\section{THE INFLUENCE OF EUROPEAN INTEGRATION AND REGIONAL COOPERATION ON THE REGIONAL POLICY OF MARKET ECONOMIES}

\section{GYULA HORVÁTH}

In the $1970 \mathrm{~s}$, the expansion phase of monopolistic accumulation was changed for a decentralized phase of economic development based on strong market role in the developed indusrial countries. The role of energy intensive industries, which had been the driving force of development earlier, decreased, and the number of people employed in services was higher than that of those employed in traditional production. Services have more flexible and new spatial demands than traditional sectors.

The new economic paradigm, which is based on small and medium enterprises instead of Fordist large units expressedly influenced the development of regional policy. Previously developed consents changed. Economic restructuring came to the forefront of government economic policies. Limited central budgets and favoured new economic branches (tertiary and 
quaternary sectors) forced the traditional regional policy to revaluate. Traditional solutions lost their earlier economic and political importance, and the outlines of new regional strategies were drawn. It is not accidental, that at the turn of the 1970s and 1980s, almost all the West European countries elaborated new legislation for regional policy, or at least significantly modernized the earlier ones.

Parallel with the changes in national regional policy meeting economic changes, the regional policy of EEC was also amended. The need for a new srategy was partly born out of the need to harmonize the policies of member countries, and partly to grant programs and means to moderate regional differences which became increasingly emphasized with the growth of EEC.

In the meantime, the regional and power structure of West European countries also changed. The political manifestation of economic decentralization was the new division of labour between the central governments and the regional local governments. The regional government who got more titles and more power, partly became capable of being the initiators of new national regional policies, and partly to become the regional basis of post- $1992 \mathrm{EEC}$ reform activities.

The author believes, that in the decade to come, the regional policy of developed European societies will develop at the crossing of the post- Fordist economic policy of ,flexible" accumulation, the regional policy of EEC, the decentralized power, and regionalism.

In his study, the author deals with the analyses of the last two elements.

In the first part of the paper, the regional differences of EEC are investigated. The second part reviews the different means of community regional policy.

In summary: Hungary' s associate membership in EEC requires, that the country' s regional policy should be developed in the direction, that power among the central government, the local authorities and their regional communities should be devided so that adaptation to modernization centres should not only be influenced by central norms, but autonomous local and regional decisions should give answers to the market and development challenges. 